\title{
PENERAPAN MODEL PEMBELAJARAN "PROJECT BASED LEARNING" PADA MATA KULIAH PEMBELAJARAN PENDIDIKAN KEWARGANEGARAAN SEKOLAH DASAR DI UNISNU JEPARA
}

\author{
Syailin Nichla Choirin Attalina \\ Pendidikan Guru Sekolah Dasar, FTIK, Unisnu Jepara \\ Email: syailin@unisnu.ac.id
}

\section{Info Artikel}

\section{Sejarah Artikel:}

Diserahkan 14 April 2020

Direvisi 07 Mei 2020

Direvisi 12 Mei 2020

Disetujui 15 Mei 2020

\section{Keywords:}

learning outcomes,

civil education

project based learning,

\section{Abstract}

This study aims to improve students learning outcomes in Civil Education Learning courses through Project Based Learning Model.

The research method used is a mix method with Classroom Action Research Method and Kurt Lewin Model. The target of this research is focused on Civil Education Learning Lectures in the odd semester 2018/2019. The Research was conducted at the Elementary School Teacher Education Program, Fakulty of Teacher Training and Education, University of Islamic Nahdlatul Ulama Jepara. There are data collection techniques used in this study, namely observation, documentation and test. The data analysis techniques use descriptive statistic analysis.

The result showed that the application of project based learning model can improve students learning outcomes in Civil Education Learning courses with indicator learning is learning outcomes of cognitive with increase in the percentage of learning outcomes on cognitive between cycle I and cycle II on $21 \%$, affective on $35 \%$ and psicomotoric on $30 \%$.

\begin{abstract}
Abstrak
Penelitian ini bertujuan untuk meningkatkan hasil belajar belajar mahasiswa pada mata kuliah pembelajaran Pendidikan Kewarganegaraan Sekolah Dasar melalui model pembelajaran "project based learning".

Metode yang digunakan dalam penelitian ini adalah mix method dengan metodologi penelitian tindakan kelas model Kurt Lewin. Sasaran penelitian ini terfokus pada mata kuliah pembelajaran Pendidikan Kewarganegaraan SD pada semester ganjil 2018/2019. Penelitian ini dilaksanakan pada Program Studi Pendidikan Guru Sekolah Dasar, Fakultas Tarbiyah dan Ilmu Keguruan, Universitas Islam Nahdlatul Ulama Jepara. Teknik pengumpulan data yang digunakan dalam penelitian ini yaitu observasi, dokumentasi dan tes. Teknik analisis data menggunakan analisis statistik deskriptif.

Hasil penelitian menemukan bahwa penerapan model Project Based Learning dapat meningkatkan hasil belajar mahasiswa pada mata kuliah pembelajaran Pendidikan Kewarganegaraan SD dengan indikator yaitu hasil belajar mahasiswa pada aspek kognitif dengan kenaikan persentase ketuntasan hasil belajar pada aspek kognitif antara siklus I dan siklus II sebesar $21 \%$, afektif sebesar $35 \%$ dan psikomotorik $30 \%$.
\end{abstract}

(C) 2020 Universitas Muria Kudus 


\section{PENDAHULUAN}

Pembelajaran

Kewarganegaraan SD merupakan salah satu mata kuliah yang terdapat dalam kurikulum Program Studi Pendidikan Guru Sekolah Dasar, Fakultas Tarbiyah dan Ilmu Keguruan, Universitas Islam Nahdlatul Ulama Jepara. Berdasarkan Rencana Pembelajaran Semester Mata kuliah Pembelajaran Pendidikan Kewarganegaraan SD, mata kuliah ini memberi bekal mahasiswa dalam merancang perencanaan, pelaksanaan dan evaluasi pembelajaran Pendidikan Kewarganegaraan SD. Perangkat pembelajaran yang dibuat oleh mahasiswa berupa perencanaan pembelajaran dalam bentuk silabus dan RPP, video pembelajaran dan penilaian dalam pembelajaran Pendidikan Kewarganegaraan SD.

Tetapi pada kenyataannya, pembelajaran pada mata kuliah pembelajaran Pendidikan Kewarganegaraan SD belum sesuai dengan yang diharapkan oleh dosen, permasalahan yang ditemui yaitu mahasiswa belum aktif pada saat proses pembelajaran berlangsung dan prestasi belajarnya masih rendah. Hal ini dibuktikan dengan nilai mahasiswa pada ulangan tengah semester ganjil 2018/2019 yang belum maksimal. Kriteria ketuntasan minimal yang ditentukan yaitu 70. Hasil evaluasi dari 33 mahasiswa, mahasiswa yang tuntas kriteria ketuntasan minimal sebanyak 14 mahasiswa $(42 \%)$ dan mahasiswa tidak tuntas KKM sebanyak 19 mahasiswa (58\%). Hal tersebut menunjukkan bahwa hasil belajar mata kuliah pembelajaran Pendidikan Kewarganegaraan SD pada kelas 3PGSDA2 tahun ajaran 2018/2019 masih rendah.

Menurut hasil observasi dan refleksi yang telah dilakukan, permasalahan tersebut dipengaruhi oleh dosen yang hanya berpatokan pada media powerpoint saja tanpa menggunakan referensi lain, penggunaan metode pembelajaran yang masih sangat sederhana yaitu metode ceramah sehingga kurang menunjukkan adanya interaksi antara mahasiswa dengan dosen, banyak mahasiswa yang belum berani mengungkapkan gagasan dan ide-ide baru mereka. Sehingga dalam pembelajaran perlu adanya suatu inovasi model pembelajaran yang menyenangkan dan mendorong mahasiswa untuk mampu meningkatkan hasil belajar.
Model pembelajaran merupakan suatu konseptual yang mempunyai prosedur yang sistematis dan diterapkan dalam pembelajaran dengan tujuan agar pembelajar dapat berjalan dengan baik dan dapat mencapai indikator pembelajaran dengan maksimal, baik indikator pembelajaran dari aspek kognitif, afektif maupun psikomotorik. Lebih lanjut Ardianti, Ulya, dan Ismaya (2018) menyatakan bahwa model pembelajaran merupakan kemasan lengkap dari semua kegiatan pembelajaran. Model pembelajaran mempunyai bagian di dalamnya, diantaranya yaitu pendekatan, strategi, metode, dan teknik pembelajaran. Untuk mengatasi permasalahan yang telah dikemukakan di atas, peneliti melakukan perbaikan hasil belajar pembelajaran dengan menerapkan model pembelajaran Project Based Learning.

Model Project Based Learning menurut Buck Institute For Education (BIE) dalam Trianto (2014) yaitu pembelajaran yang melibatkan siswa dalam kegiatan pembelajaran baik dalam memecahkan suatu permasalahan dan memberikan peluang bagi siswa untuk lebih mengekspresikan kreatifitas mereka sehingga dapat meningkatkan hasil belajar siswa. Hal ini diperkuat oleh Hartono (2018) yang menyatakan bahwa pembelajaran PjBL adalah model pembelajaran yang melibatkan suatu proyek dalam proses pembelajaran, proyek yang dikerjakan peserta didik dapat berupa proyek per-orangan atau kelompok dan dilaksanakan dalam jangka waktu tertentu secara kolaborasi, menghasilkan suatu produk, yang hasilnya akan dipresentasikan.

Dalam penerapannya mahasiswa berperan aktif dalam pembuatan proyek sehingga dapat memberikan pengalaman kepada mahasiswa untuk dapat membangun suatu pengetahuannya sendiri. Selain itu, dalam penerapan Model Project Based Learning kemampuan mahasiswa benar-benar dioptimalkan melalui kerja kelompok/tim yang sistematis, sehingga mahasiswa dapat memberdayakan, mengasah, menguji dan mengembangkan kemampuan berpikirnya secara berkelanjutan.

Sari (2017) menyatakan bahwa Model Project Based Learning memiliki keunggulan yaitu: (1) peserta didik termotivasi dalam pembelajaran khususnya dalam kegiatan pembuatan proyek; (2) menuntut peserta didik 
agar lebih kreatif dalam pembelajaran dan mampu memecahkan masalah; (3) meningkatkan kolaborasi antar peserta didik serta (4) memunculkan sikap ilmiah seperti jujur, teliti, tanggung jawab dan kreatif. Berdasarkan keunggulan Model Project Based Learning diharapkan dapat meningkatkan hasil belajar mahasiswa dalam proses pembelajaran.

Susanto (2013) menjelaskan bahwa hasil belajar yaitu perubahan-perubahan yang terjadi pada siswa, baik perubahan yang berkaitan dengan aspek pengetahuan, sikap dan keterampilan sebagai hasil dari kegiatan pembelajaran yang telah dilakukan.

Menurut Susanto (2013) menyatakan bahwa faktor-faktor yang mempengaruhi hasil belajar yaitu kecerdasan anak, kesiapan atau kematangan siswa dalam kegiatan belajar, minat siswa dalam belajar, model penyajian materi pembelajaran yang disediakan oleh guru, dan suasana belajar yang menyenangkan sehingga membuat siswa menjadi lebih senang dalam pembelajaran.

Penelitian Surya (2018) membuktikan bahwa penggunaan model Project Based Learning (PjBL) dapat meningkatkan hasil belajar dan kreatifitas siswa kelas III SD Negeri Lor Salatiga, hal ini terlihat pada peningkatan belajar siswa yakni pada prasiklus ketuntasan belajar siswa sebesar $46 \%$ lalu meningkat sebesar $72 \%$ pada siklus I dan meningkat lagi pada siklus II sebesar $92 \%$ ketuntasan siswa. Selain pada hasil belajar, kreatifitas siswa dari setiap pertemuan mengalami peningkatan, yanag pada awalnya sebesar $27 \%$ pada pra siklus meningkat menjadi $50 \%$ pada pertemuan 1 siklus I lalu meningkat Kembali menjadi $51 \%$ pada pertemuan II dan pada siklus II kreatifitas siswa meningkat menjadi $80 \%$ pertemuan I dan meningkat menjadi $90 \%$ pada pertemuan 2 siklus II. Perbedaan penelitian ini dengan penelitian yang dilakukan oleh Surya yaitu terletak pada fokus penelitian. Penelitian Surya berfokus pada pembelajaran di SD, sedangkan pada penelitian ini berfokus pada hasil belajar pada Mata Kuliah pembelajaran Pendidikan Kewarganegaraan SD.

Penelitian Sitaresmi

menyatakan bahwa model Project Based Learning pada materi sifat keperiodikan unsur siswa kelas X MIA 1 SMA Negeri 1 Teras Boyolali dapat meningkatkan aktivitas belajar dan prestasi belajar. Perbedaan penelitian ini dengan penelitian yang dilakukan oleh Sitaresmi yaitu fokus penelitiannya, penelitian Sitaresmi berfokus pada aktivitas dan prestasi belajar di SMA, sedangkan pada penelitian ini berfokus pada hasil belajar yang meliputi aspek kognitif, afektif dan psikomotorik pada mahasiswa.

Penelitian sebelumnya mengenai Model Project Based Learning dilakukan oleh Sarwono (2016) yang menyatakan Model Project Based Learning sangat efektif dalam upaya meningkatkan pengetahuan bencana alam di Indonesia dan perilaku cinta lingkungan siswa kelas X SMA Negeri 2 Surakarta. Fokus penelitian tersebut membahas tentang peningkatan pengetahuan dan perilaku siswa, sedangkan pada penelitian ini meliputi peningkatan pengetahuan, perilaku dan keterampilan mahasiswa.

Berdasarkan keseluruhan uraian di atas, maka peneliti tertarik melakukan penelitian berjudul "Penerapan Model Pembelajaran Project Based Learning pada Mata Kuliah Pembelajaran Pendidikan Kewarganegaraan SD di Unisnu Jepara" dengan rumusan masalah sebagai berikut : (1) Bagaimana Perkuliahan Pembelajaran Pendidikan Kewarganegaraan SD di Prodi PGSD Unisnu Jepara?; (2) Bagaimana Penerapan Model Project Based Learning pada Mata Kuliah Pembelajaran Pendidikan Kewarganegaraan SD?; (3) Bagaimana Hasil Belajar pada Aspek Kognitif, Afektif dan Psikomotorik Mata Kuliah Pembelajaran Pendidikan Kewarganegaraan SD?

\section{METODE PENELITIAN}

Pendekatan penelitian yang digunakan yaitu mix method dengan metodologi penelitian Tindakan kelas. Adapun desain PTK menggunakan model PTK Kurt Lewin. Menurut Bryman \& Bell (2011) Penelitian Tindakan diartikan sebagai "pendekatan di mana peneliti tindakan dan klien berkolaborasi dalam suatu diagnosis masalah dan dalam pengembangan solusi berdasarkan diagnosis. Penelitian Tindakan Kelas ini dilakukan sebanyak 2 siklus dengan masing-masing siklus terdiri dari 4 tahap yaitu (1) perencanaan; (2) pelaksanaan; pengamatan; dan (3) refleksi. Adapun gambar desain penelitian yang digunakan dalam penelitian ini yaitu : 


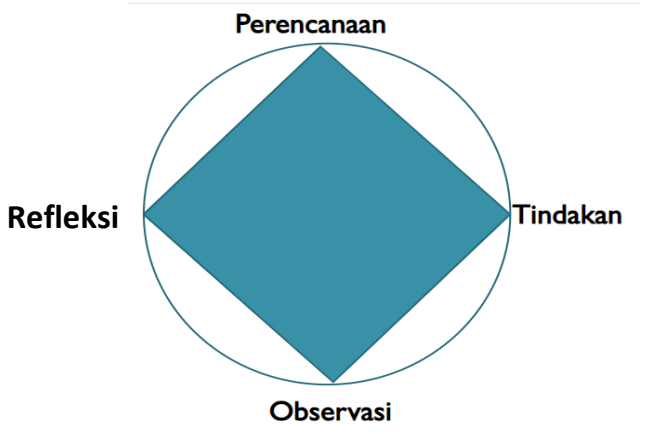

Gambar 1. Desain Penelitian

Subjek penelitian adalah mahasiswa kelas 3PGSDA2 Tahun Ajaran 2018/2019 dengan mahasiswa berjumlah 38 mahasiswa yang terdiri 30 mahasiswi dan 8 mahasiswa. Selanjutnya, Teknik dan instrument penelitian ini disajikan pada tabel 1 berikut ini:

Tabel 1. Teknik dan Instrumen Penelitian

\begin{tabular}{lll}
\hline Jenis Data & Teknik & Instrumen \\
\hline Hasil Belajar Kognitif & Tes & Soal \\
\hline Hasil Belajar Afektif & Observasi & Rubrik Penilaian Sikap \\
\hline Hasil Belajar Psikomotorik & Observasi & Rubrik Penilaian Keterampilan \\
\hline
\end{tabular}

\begin{abstract}
Adapun teknik analisis data menggunakan statistik deskriptif yaitu penyajian data, mean, persentil dan range. Statistik deskriptif pada penelitian ini hanya menerangkan kelompok data saja tanpa melakukan generalisasi.
\end{abstract}

\section{HASIL DAN PEMBAHASAN}

Mata Kuliah Pembelajaran Pendidikan Kewarganegaraan SD merupakan salah satu mata kuliah wajib yang terdapat dalam kurikulum Program Studi Pendidikan Guru Sekolah Dasar, Fakultas Tarbiyah dan Ilmu Keguruan, Universitas Islam Nahdlatul Ulama Jepara. Mata kuliah Pembelajaran Pendidikan Kewarganegaraan SD memberi bekal mahasiswa dalam merancang perencanaan, pelaksanaan dan evaluasi pembelajaran Pendidikan Kewarganegaraan SD (Rencana Pembelajaran Semester Pembelajaran Pendidikan Kewarganegaraan SD, 2019).

Materi pada perkuliahan Pembelajaran Pendidikan Kewarganegaraan SD yaitu materi teori dan praktik. Materi teori meliputi konsep Pendidikan Kewarganegaraan di SD, Karakteristik guru dalam pembelajaran Pendidikan Kewarganegaraan SD, Strategi dan Model Pembelajaran Pendidikan
Kewarganegaraan SD, sedangkan praktiknya yaitu Menyusun perencanaan, pelaksanaan dan penilaian pembelajaran Pendidikan Kewarganegaraan SD.

Metode pembelajaran yang digunakan pada perkuliahan pembelajaran Pendidikan Kewarganegaraan SD yaitu metode ceramah, demonstrasi, drill, penugasan berupa pemecahan masalah berbasis project based learning. Masing-masing metode digunakan secara bergantian dengan disesuaikan dengan karakteristik setiap materi yang diberikan kepada mahasiswa. Beberapa metode pembelajaran diterapkan dengan harapan agar perkuliahan menjadi lebih menarik dan membangkitkan motivasi mahasiswa sehingga materi menjadi lebih mudah diterima oleh mahasiswa dan dapat meningkatkan hasil belajar pada keseluruhan aspek yaitu kognitif, afektif dan psikomotorik.

Penerapan Model Project Based Learning pada Mata Kuliah Pembelajaran Pendidikan Kewarganegaraan SD dilakukan melalui tahap perencanaan, peneliti mempersiapkan perangkat pembelajaran diantaranya yaitu Satuan Acara Perkuliahan (SAP), Rencana Pembelajaran Semester (RPS), materi ajar berupa Power Point Text, 
Lembar Kerja Mahasiswa dan Instrumen Penelitian. Instrumen Penelitian yang dipersiapkan yaitu kisi-kisi soal tes akhir siklus I dan siklus II yang masing-masing terdiri dari 25 soal, kunci jawaban soal tes, pedoman penilaian dan lembar penilaian sikap dan keterampilan mahasiswa sekaligus rubrik penilaiannya.

Proyek dalam penerapan Model Project Based Learning pada Mata Kuliah Pembelajaran Pendidikan Kewarganegaraan SD ini ada penyusunan Rencana Pelaksanaan Pembelajaran yang disesuaikan dengan kasus yang telah diberikan oleh dosen dan merealisasikannya dalam bentuk video pembelajaran lengkap dengan penerapan model pembelajaran dan media pembelajaran. Dimana model pembelajaran yang digunakan dideskripsikan setiap langkah-langkahnya di dalam video pembelajaran yang telah dibuat.

Pelaksanaan Model Project Based Learning pada Mata Kuliah Pembelajaran Pendidikan Kewarganegaraan SD dilakukan berdasarkan sintaksnya yaitu : (1) dosen memberikan pertanyaan mendasar terkait materi di setiap pertemuan di siklus I maupun siklus II; (2) dosen membentuk kelompok bersifat heterogen; (3) dosen memberikan suatu kasus untuk dipecahkan melalui perencanaan proyek serta menyusun jadwal aktivitas dalam penyelesaian proyek; (4) dosen memonitoring sejauh mana proyek yang sudah dibuat oleh mahasiswa; (5) menguji proyek yang sudah diselesaikan oleh tiap kelompok; (6) presentasi produk dan melakukan evaluasi.

Selanjutnya, pada tahap observasi peneliti menggunakan lembar pengamatan sikap dan keterampilan mahasiswa, kegiatan observasi ini dilakukan oleh peneliti pada saat proses pembelajaran dan pembuatan video pembelajaran dengan panduan penilaian yang sudah dibuat dalam bentuk rubrik penilaian. Tahap yang terakhir yang dilakukan yaitu tahap refleksi, pada tahap ini dosen melakukan refleksi dari hasil penilaian dari aspek kognitif, afektif dan psikomotorik.

\section{Hasil Belajar pada Aspek Kognitif Mata Kuliah Pembelajaran Pendidikan Kewarganegaraan SD}

Berdasarkan hasil penelitian dapat dilihat bahwa terdapat peningkatan hasil belajar pada aspek kognitif mata kuliah pembelajaran Pendidikan Kewarganegaraan SD dengan menerapkan model pembelajaran Project Based Learning dari siklus I sampai siklus II. Hal ini dibuktikan dengan kenaikan persentase ketuntasan hasil belajar pada aspek kognitif antara siklus I dan siklus II sebesar $21 \%$. Berdasarkan data tersebut, dapat disimpulkan hasil belajar pada aspek kognitif mahasiswa 3PGSDA2 TA 2018/2019 sudah memenuhi kriteria ketuntasan klasikal $(>85 \%)$. Hasil belajar pada aspek kognitif pada tiap siklus ditunjukkan pada tabel 2 berikut

Tabel 2. Hasil Belajar Aspek Kognitif pada kegiatan Prasiklus, Siklus I dan Siklus II

\begin{tabular}{lccc}
\hline Pencapaian & Prasiklus & Siklus I & Siklus II \\
\hline Nilai Rata-rata Kelas & 70 & 75 & 85 \\
\hline Nilai tertinggi & 80 & 85 & 95 \\
\hline Nilai terendah & 45 & 50 & 55 \\
\hline Mahasiswa memenuhi KKM & 14 & 21 & 28 \\
\hline Mahasiswa belum memenuhi kkm & 21 & 12 & 5 \\
\hline Persentase Ketuntasan Belajar Klasikal & $43 \%$ & $64 \%$ & $85 \%$ \\
\hline
\end{tabular}

Dari tabel hasil belajar aspek kognitif mahasiswa 3PGSDA2 TA 2018/2019 dari prasiklus, siklus I dan siklus II dapat disajikan dalam bentuk gambar 2 berikut ini. 


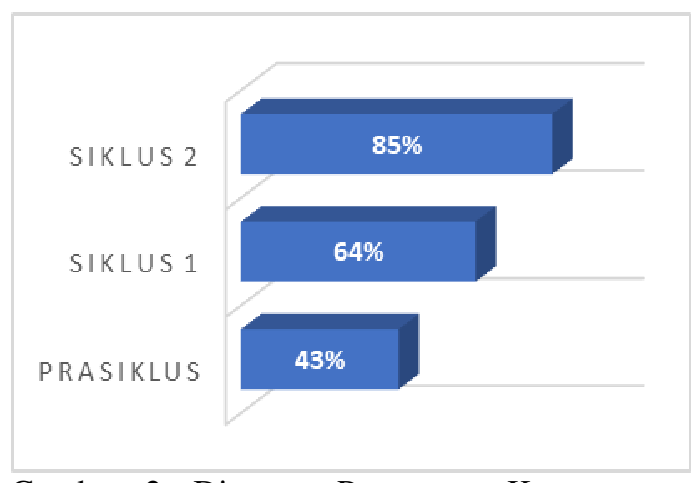

Gambar 2. Diagram Persentase Ketuntasan Belajar Klasikal Hasil Belajar Aspek Kognitif

\section{Hasil Belajar pada Aspek Afektif Mata Kuliah Pembelajaran Pendidikan Kewarganegaraan SD}

Berdasarkan hasil penelitian dapat dilihat bahwa terdapat peningkatan hasil belajar aspek afketif mata kuliah pembelajaran Pendidikan Kewarganegaraan SD dengan menerapkan model pembelajaran Project Based Learning dari siklus I sampai siklus II. Hal ini dibuktikan dengan kenaikan persentase ketuntasan hasil belajar aspek afektif antara siklus I dan siklus II sebesar $40 \%$. Berdasarkan data tersebut, dapat disimpulkan hasil belajar mahasiswa 3PGSDA2 TA 2018/2019 sudah memenuhi kriteria ketuntasan klasikal (>85\%). Hasil belajar pada aspek kognitif pada tiap siklus ditunjukkan pada tabel 3 berikut ini.

Tabel 3. Hasil Belajar Aspek Afektif pada kegiatan Prasiklus, Siklus I dam Siklus II

\begin{tabular}{llccc}
\hline nilai & & prasiklus & siklus 1 & siklus 2 \\
\hline$>\mathbf{3}$ & tuntas & 14 & 18 & 30 \\
\hline $\mathbf{3}$ & $\begin{array}{l}\text { tidak } \\
\text { tuntas }\end{array}$ & 19 & 15 & 3 \\
\hline & & $42 \%$ & $55 \%$ & $90 \%$ \\
\hline
\end{tabular}

Peningkatan ketuntasan hasil belajar aspek afektif mahasiswa 3PGSDA2 TA 2018/2019 dari prasiklus, siklus I dan siklus II dapat disajikan dalam bentuk gambar 3 berikut ini.

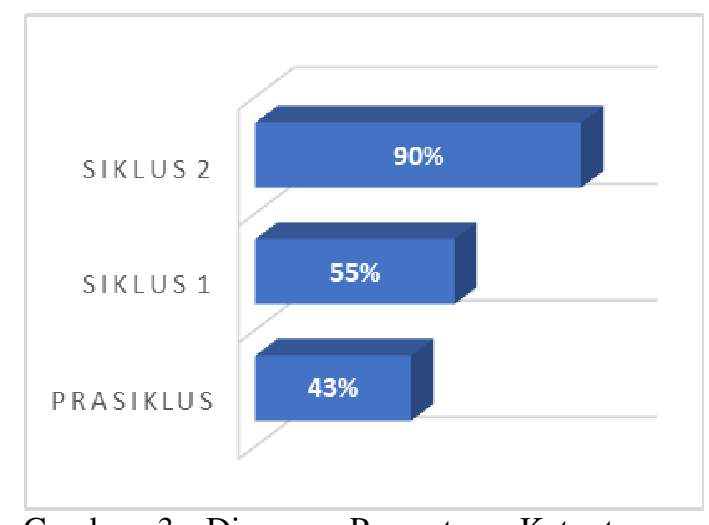

Gambar 3. Diagram Persentase Ketuntasan Belajar Klasikal Hasil Belajar pada Aspek Afektif

Hasil Belajar pada Aspek Psikomotorik Mata Kuliah Pembelajaran Pendidikan Kewarganegaraan SD

Berdasarkan hasil penelitian dapat dilihat bahwa terdapat peningkatan hasil belajar aspek psikomotorik mata kuliah pembelajaran Pendidikan Kewarganegaraan SD dengan menerapkan model pembelajaran Project Based Learning dari siklus I sampai siklus II. Hal ini dibuktikan dengan kenaikan persentase ketuntasan hasil belajar aspek psikomotorik antara siklus I dan siklus II sebesar $30 \%$. Berdasarkan data tersebut, dapat disimpulkan hasil belajar mahasiswa 3PGSDA2 TA 2018/2019 sudah memenuhi kriteria ketuntasan klasikal $(>85 \%)$. Hasil belajar pada aspek kognitif pada tiap siklus ditunjukkan pada tabel 4 berikut ini.

Tabel 4. Hasil Belajar Aspek Psikomotorik pada kegiatan Prasiklus, Siklus I dam Siklus II

\begin{tabular}{llccc}
\hline nilai & & prasiklus & siklus 1 & siklus 2 \\
\hline$>\mathbf{3}$ & tuntas & 13 & 19 & 29 \\
\hline$<3$ & $\begin{array}{l}\text { tidak } \\
\text { tuntas }\end{array}$ & 20 & 14 & 4 \\
\hline & & $39 \%$ & $58 \%$ & $88 \%$ \\
\hline
\end{tabular}

Peningkatan ketuntasan hasil belajar aspek psikomotorik mahasiswa 3PGSDA2 TA 2018/2019 dari prasiklus, siklus I dan siklus II dapat disajikan dalam bentuk gambar 4 berikut ini. 


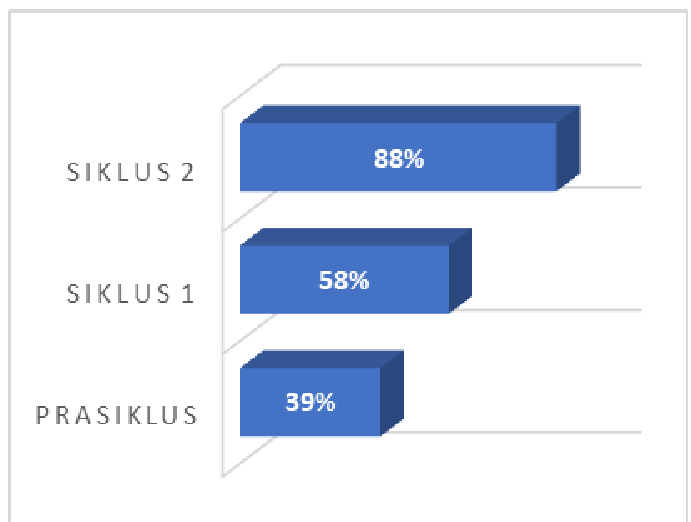

Gambar 4. Diagram Persentase Ketuntasan Belajar Klasikal Hasil Belajar Aspek Psikomotorik

Dari hasil penelitian di atas dapat disimpulkan bahwa penerapan model Project Based Learning dapat meningkatkan hasil belajar mahasiswa baik pada aspek kognitif, afektif dan psikomotorik mata kuliah pembelajaran Pendidikan Kewarganegaraan SD pada kelas 3PGSDA2 TA 2018/2019. Hasil penelitian di atas didukung oleh penelitian sebelumnya yang dilakukan oleh Triani, et al (2015) menyatakan bahwa Model PjBL dapat meningkatkan hasil belajar pada mata pelajaran Geografi pada jenjang SMA. Perbedaan penelitian tersebut dengan penelitian ini yaitu jenjang dan mata pelajaran, penelitian ini dilakukan pada jenjang perguruan tinggi dan berfokus pada mata kuliah pembelajaran pendidikan kewarganegaraan SD sedangkan penelitian Triani dilakukan pada jenjang SMA dan berfokus pada mata pelajaran Geografi.

Hal ini diperkuat oleh penelitian yang dilakukan oleh Karacalli, et al (2014) dan Mohammadi (2018). Karacalli, et al (2014) mengemukakan bahwa penerapan PjBL dapat meningkatkan hasil belajar pada mata pelajaran IPA di SD, perbedaan penelitian tersebut dengan penelitian ini yaitu jenjang dan mata pelajaran, penelitian ini dilakukan pada jenjang perguruan tinggi dan berfokus pada mata kuliah pembelajaran pendidikan kewarganegaraan SD sedangkan penelitian Karacalli, dkk dilakukan pada jenjang SD dan berfokus pada mata pelajaran IPA. Sedangkan penelitian yang dilakukan oleh Mohammadi (2018) menjelaskan bahwa penerapan PjBL efektif dalam meningkatkan keaktifan dan partisipasi mahasiswa dalam pembelajaran, penelitian Mohammadi berfokus pada keaktifan dan partisipasi mahasiswa, sedangkan penelitian ini berfokus pada hasil belajar mahasiswa.

Hal di atas juga diperkuat oleh penelitian yang dilakukan oleh riset Kokotsaki, et al (2016) dan penelitian Pratiwi, Ardianti, dan Kanzunnudin (2018) serta riset Almujab et al (2018). Penelitian Kokotsaki, et al (2016) menyatakan bahwa penerapan PjBL berperan penting dalam memfasilitasi proses pembelajaran di jenjang TK, SD, SMP, SMA bahkan Perguruan Tinggi. Riset Pratiwi, Pratiwi, Ardianti, dan Kanzunnudin (2018) (2018) mengemukakan bahwa model project based learning berbantuan metode edutainment dapat meningkatkan kemampuan kerjasama dan hasil belajar siswa. Sedangkan penelitian Almujab et al (2018) menyatakan sebagian besar peserta didik merasa senang dengan pembelajaran ekonomi dengan menggunakan metode belajar PBL. Hal ini disebabkan karena pembelajaran dengan menggunakan PBL mampu membangkitkan aktifitas belajar mahasiswa dalam pembelajaran

\section{SIMPULAN}

Berdasarkan analisis hasil dan pembahasan penelitian dapat disimpulkan bahwa penerapan model pembelajaran Project Based Learning dapat meningkatkan hasil belajar mahasiswa pada mata kuliah pembelajaran Pendidikan Kewarganegaraan SD Prodi PGSD Unisnu Jepara dengan indikator yaitu meningkatnya hasil belajar mahasiswa pada aspek kognitif, afektif dan psikmotorik dengan masing-masing kenaikan persentase ketuntasan hasil pada aspek kognitif yaitu $21 \%$, aspek afektif sebesar 35\% dan aspek psikomotorik sebesar $30 \%$.

Saran yang diberikan berdasarkan hasil penelitian yaitu sebaiknya dosen menerapkan model pembelajaran dan menggunakan media pembelajaran yang inovatif dalam proses pembelajaran agar keaktifan mahasiswa dapat meningkat sehingga pada akhirnya memperoleh hasil belajar pada aspek kognitif, afektif dan psikomotorik yang baik. Selain itu, dalam penerapannya, dosen harus mempersiapkan media pembelajaran dengan baik dan memanfaatkan waktu dengan optimal. 


\section{DAFTAR PUSTAKA}

Almujab, Saiful., et al. 2018. Penerapan Lesson Study Melalui Metode Project Based Learning Untuk Meningkatkan Keaktifan Mahasiswa Dalam Proses Pembelajaran Di FKIP UNPAS. Jurnal Refleksi Edukatika. 8 (2): 139-148.

Ardianti, Sekar Dwi., Ulya, Himmatul., dan Ismaya, Erik Aditia. 2018. PAKEM DALAM KURIKULUM 2013 : Teori dan Praktek. Kudus: Badan Penerbit Universitas Muria Kudus.

Bryman, A., and Bell, E. 2011. Business Research Methods. New York: Oxford University Press.

Hartono, Puji. D., dan Siti Aisyah. 2018. PjBL untuk Meningkatkan Kreativitas Mahasiswa: Sebuah Kajian Deskriptif tentang Peran Model Pembelajaran PjBL dalam Meningkatkan Kreativitas Mahasiswa. Prosiding

Karacalli, Saide and Fikret Korur. 2011. The Effect of Project-Based Learning on Students Academic Achievement, Attitude, and Retention of Knowledge: The Subject of "Electricity in Our Lives. The Effects of Project-Based Learning. School Science and Mathematics. 114 (5)

Kokotsaki, D., Menzies, D., and Wiggins, A. 2016. Project-based learning: A review of the literature. Journal of Improving School. 19 (3): 267-277.

Mohammadi, Zohri. 2018. Comparative Effect of Project-Based Learning and Electronic Project-Based Learning on The Development and Sustained Edevelopment of English Idiom Knowledge. Journal of Comput High Education. 30 (1): 363-385

Pratiwi, Ika Ari., Sekar D.A., dan Moh. Kanzunnudin. 2018. Peningkatan Kemampuan Kerjasama Melalui Model Project Based Learning (PjBL) berbantuan Metode Edutainment Pada Mata Pelajaran Ilmu Pengetahuan
Sosial. Refleksi Edukatika : Jurnal Ilmiah Kependidikan, 8 (2): 177-182.

Sari, D.P. 2017. Meningkatkan Kreativitas Belajar Siswa menggunakan Model Pembelajaran Project Based Learning pada Mata Pelajaran IPA di Kelas VB SD Negeri 34/1 Teratai. Skripsi. Jambi: Universitas Jambi.

Sarwono, Sigit, S., dan Soegiyanto, S.U., 2016. Pengaruh Model Pembelajaran Project Based Learning Terhadap Pengetahuan Bencana Alam di Indonesia dan Perilaku Cinta Lingkungan Hidup. Jurnal GeoEco. 2 (2): 184-197.

Sitaresmi, Kun Sasamti., Sulistya S., DAN Suryadi B.U., 2017. Penerapan Pembelajaran Project Based Learning (PjBL) untuk Meningkatkan Aktivitas dan Prestasi Belajar Siswa pada Materi Sistem Periodik Unsur (SPU) Kelas X MIA 1 SMA Negeri 1 Teras Boyolali. Jurnal Pendidikan Kimia. 6(1): 54-61.

Surya, Andita, P,. Stefanus C.R., dan Agustina, T.A.H., 2018. Penerapan Pembelajaran Project Based Learning $(P j B L)$ untuk Meningkatkan Hasil Belajar dan Kreatifitas Siswa Kelas III SD Negeri Sidorejo Lor 01 Salatiga. Jurnal Pesona Dasar. 6 (1): 41-54.

Susanto, Ahmad. 2013. Teori Belajar dan Pembelajaran di Sekolah Dasar. Jakarta: Kencana Prenada Media Group.

Triani, Wina, Zulkarnanin, Z., dan Utami, RKS. 2015 Pengaruh Model Pembelajaran Project Based Learning Terhadap Hasil Belajar Geografi. Jurnal Ilmiah Pendidikan Geografi. 3(7).

$\begin{array}{crr}\text { Trianto. 2014. } & \text { Mendesain } & \text { Model } \\ \text { Pembelajaran } & \text { Inovatif-Progresif: } \\ \text { Konsep, } & \text { Landasan, } & \text { dan } \\ \text { Implementasinya } & \text { Pada } & \text { Kurikulum } \\ 2013 \text { (Kurikulum } & \text { Tematik } & \text { Integratifl } \\ \text { KTI). Jakarta: Kencana Predana Media } \\ \text { Group. }\end{array}$

